\title{
Cyanides Reduction and Pasting Properties of Cassava (Manihot Esculenta Crantz) Flour as Affected by Fermentation Process
}

\author{
Nardis Ze Nkoudou1, Jean Justin Ngang Essia ${ }^{2 *}$ \\ ${ }^{1}$ Department of Biochemistry, Faculty of Science, The University of Yaoundé 1, Yaounde, Cameroon \\ ${ }^{2}$ Department of Microbiology, Faculty of Science, The University of Yaoundé 1, Yaounde, Cameroon \\ Email: *essia_ngang@yahoo.fr
}

How to cite this paper: Nkoudou, N.Z. and Essia, J.J.N. (2017) Cyanides Reduction and Pasting Properties of Cassava (Manihot Esculenta Crantz) Flour as Affected by Fermentation Process. Food and Nutrition Sciences, 8, 326-333.

https://doi.org/10.4236/fns.2017.83022

Received: February 11, 2017

Accepted: March 18, 2017

Published: March 22, 2017

Copyright $\odot 2017$ by authors and Scientific Research Publishing Inc. This work is licensed under the Creative Commons Attribution International License (CC BY 4.0).

http://creativecommons.org/licenses/by/4.0/

\begin{abstract}
BACKGROUND: The effect of fermentation process on total cyanides content reduction and pasting properties of cassava flour was evaluated. The fermentation process studied was spontaneous fermentation (SF) and the fermentation with the addition of mixed-starter at the 0 hour of fermentation (FAS). Unfermented cassava flour (UCF) was also produced to serve as a control. Total cyanides and pasting properties of flours from the fermented cassava were compared with unfermented flour. RESULTS: The results showed that the addition of mixed-starter effected a significant reduction in total cyanides level (79.6\% to 99\%) depending on the fermentation period. Pasting properties of cassava flour were also affected by fermentation process. SF flour paste (stability ratio $=0.6$ ) was more resistant to shear thinning than FAS and UCF (stability ratio $=0.5$ ) indicating that, SF flour has the ability to withstand severe processing conditions better than FAS and UCF pastes. Fermentation up to $48 \mathrm{~h}$ had resulted in cassava flour SF having a higher peak viscosity value $(6615 \mathrm{cP})$, but did not affect the tendency to retrograde. CONCLUSION: The use of mixed-starter in fermentation greatly reduced cyanide intake of the population in Africa and has potential to eliminate Konzo without significant modifications of flour properties.
\end{abstract}

\section{Keywords}

Detoxification, Viscosity, Mixed-Starter, Fermentation

\section{Introduction}

Cassava is the first most important root crop cultivated in tropical and subtropical regions of the world. More than the half of the worlds' cassava production comes from Africa; with Cameroon being the 19th world's leading producer [1]. 
Cassava tuber is highly starchy which makes "fufu" preparation easy and can equally be prepared and eaten whole like cocoyam (Colocassia esculenta) [2]. Cassava can also be processed in several ways to produce different food products. Among the processes cassava can be subjected to, are "gari" production, boiling, flour for baking, soup thickeners, specialty food for gastrointestinal disorders and fermented flour which is cooked in boiled water to form a somewhat acidic paste called fufu, which is consumed with a sauce or vegetables. Several studies have shown that cassava contains digestible starch, vitamins and a low score of amino acids [3]. However, two major limiting factors in the utilization of cassava are, low shelf life and the presence in various proportions of cyanide compounds, which hydrolysis leads to the production of hydrocyanic acid (HCN), a substance toxic to humans [4] [5]. Ingestion of foods containing cyanide compounds have also been reported to cause an upper neuron disease known as "Konzo", which is characterized by abrupt onset of spastic paralysis, nausea and vomiting [6]. The presence of these cyanogenic glucosides necessitates the processing of roots prior to consumption. Fermentation not only enhances detoxification but may also improve the quality of the food under process [7]. Traditionally, fermented cassava flour is made by soaking cassava roots in water for 3 to 5 days, followed by the process of draining, drying and milling. [7] (Numfor et al., 1995) showed that changes in physicochemical properties of cassava flour produced were attributable to the spontaneous fermentation occurring during soaking. In order to reduce the time of root softening during the fermentation process, starters can be added to the fermentation medium at the beginning of the fermentation, which can modify physicochemical properties of cassava flour. Knowing that, application of flour from different plant sources in food systems depends greatly on information about the physicochemical properties of such food materials, the aim of this study was to determine the effect of fermentation on pasting properties and cyanogenic compounds of cassava flour.

\section{Material and Methods}

\subsection{Flour Sample Preparation}

Cassava roots of the bitter variety (containing a quantity of $655 \mathrm{ppm}$ of cyanides) were collected from IITA in Yaounde, Center Region Cameroon. Flours preparation was performed according to the procedure in Figure 1. The roots were cleaned, peeled, washed, and sliced into pieces of $10 \mathrm{~cm}$ long, then left to ferment in tap water for $24 \mathrm{~h}, 48 \mathrm{~h}$ and $72 \mathrm{~h}$. The fermentation studied included spontaneous fermentation (SF), i.e. water soaking of cassava roots as a control and fermentation with added starter flour (FAS) at the concentration of $1 \%$ $(\mathrm{w} / \mathrm{v})$. The fermented cassavas were drained, dried in an oven at $40^{\circ} \mathrm{C}$ for $48 \mathrm{~h}$ and milled. The flour samples were passed through a $45 \mu \mathrm{m}$ mesh size sieve. Unfermented cassava flour (UCF) was also produced to serve as a control.

\subsection{Total Cyanide Analysis of Fermented Flour}

The total cyanide content of cassava flour was determined as described by [8]. 



Figure 1. Cassava flour samples preparation procedure.

For this purpose, a $100 \mathrm{mg}$ sample was placed in a screwable plastic flask on top of a filter paper soaked with the $\mathrm{pH} 6$ buffer phosphates and Linamarase. A volume of $0.5 \mathrm{ml}$ distilled sterile water was then added in the flask as well as a yellow colored picric acid paper. The flask was immediately and hermetically closed using a screwed plug and placed at $30^{\circ} \mathrm{C}$ for $18 \mathrm{hr}$. The following day, the yellow-orange paper was taken out of the flask and put in a test tube containing 5 $\mathrm{ml}$ of sterile water and the test tube was boiled for $5 \mathrm{~min}$. The paper was taken out and the absorbance of the solution measured at $510 \mathrm{~nm}$ after cooling. The total cyanide in ppm (parts per million) was calculated by multiplying the absorbance by 396 .

\subsection{Pasting Properties Studies}

Pasting properties of flours were determined with a Rapid Visco Analyser (RVA4, New Port Scientific, PETERN Instrument-Australia). Flour suspension 12.5\% $(\mathrm{w} / \mathrm{v})(3.5 \mathrm{~g}$ dry basis suspended in distilled water and the total weight adjusted to $28 \mathrm{~g}$ ), was equilibrated $1 \mathrm{~min}$ at $50^{\circ} \mathrm{C}$, heated to $95^{\circ} \mathrm{C}$ in $5 \mathrm{~min}$. at the rate of $9^{\circ} \mathrm{C} \cdot \mathrm{min}^{-1}$, held at $95^{\circ} \mathrm{C}$ for $2 \mathrm{~min}$, cooled to $50^{\circ} \mathrm{C}$ for $5 \mathrm{~min}$ at $9^{\circ} \mathrm{C} \cdot \mathrm{min}^{-1}$ and held again at $50^{\circ} \mathrm{C}$ for $1 \mathrm{~min}$. The stirring speed was $160 \mathrm{rpm}$. From the resulting curve, the Pasting temperature (Pt), the Peak viscosity (PV), the final viscosity (FV), the Breakdown viscosity (BV) and the Setback viscosity (SV) were recorded. These data permitted to determine the percentages of gelling and drop according to the formulas below:

$$
\begin{aligned}
& \text { Setback ratio }=(\mathrm{FV} / \mathrm{BV}) \times 100 \\
& \text { Stability ratio }=(\mathrm{BV} / \mathrm{PV}) \times 100
\end{aligned}
$$

\subsection{Statistical Analysis}

All measurements were made three times. The comparison of the averages of the 
values obtained was done by ANOVA on SPSS 16.0 (SPSS International Chicago, USA) with a confidence threshold of $95 \%$. The significant differences between the averages were performed using the LSD procedure.

\section{Results and Discussion}

\subsection{Total Cyanides Content of Fermented Flours}

The results (Table 1) show that the total cyanides content of the flour decrease from $350 \mathrm{mg} \mathrm{HCN}$ equivalents. $\mathrm{kg}^{-1}$ flour (ppm) (unfermented flour) to $7.9 \mathrm{ppm}$ and $3.1 \mathrm{ppm}$ respectively for $72 \mathrm{~h}$ spontaneous fermented flour (SF) and $72 \mathrm{~h}$ flour fermented with added starter (FAS). Total cyanides content decreased with increase in fermentation period. There was a $97 \%$ and $99 \%$ reduction in cyanides content respectively for SF and FAS of the $72 \mathrm{~h}$ fermented flours when compared with unfermented cassava flour. Total cyanides content of the $24 \mathrm{~h}$ and $48 \mathrm{~h}$ fermented flours were also reduced. The most cyanide reduction was observed with flours FAS, in which the reduction percentages were $80 \%$ and $98 \%$ at $24 \mathrm{~h}$ and $48 \mathrm{~h}$ respectively compared with the $20 \%$ and $92 \%$ reductions obtained with flours SF at the same period.

The observed marked reduction caused by fermentation may be due to the effect of enzymes/acid hydrolysis of the cellular wall during the fermentation and the microbial load at the beginning of fermentation. The addition of the starter at the beginning of fermentation increases the microorganisms load in the fermentation medium indeed. Microorganisms accelerate the rate of roots softening and acidification of the medium. These two parameters are strongly correlated with the activity of the enzymes that degrade the cellular wall, phenomenon responsible for hydrolysis of the linamarine by the linamarase and then, for the detoxification [9] [10] [11] (Kabawila et al., 2005), also reported a 75\% cyanides content reduction in fermented cassava roots.

\subsection{Pasting Properties}

The effect of different methods fermentation on pasting properties of cassava flour is presented in Tables 2-4. Our results showed that pasting properties of cassava flour were affected by fermentation process. Addition of starter culture for fermentation showed more complex effect on the pasting properties and was a function of the progress of fermentation reaction.

Table 1. Total cyanides remaining in cassava flour after different hours of fermentation.

\begin{tabular}{|c|c|c|c|c|}
\hline \multirow{2}{*}{ Treatments } & \multicolumn{4}{|c|}{$\begin{array}{c}\text { Total cyanides (mg HCN equivalents. } \mathrm{kg}^{-1} \text { flour }(\mathrm{ppm}) \text { ) remaining in } \\
\text { cassava flour after different hours of fermentation }\end{array}$} \\
\hline & $0 \mathrm{~h}$ & $24 \mathrm{~h}$ & $48 \mathrm{~h}$ & $72 \mathrm{~h}$ \\
\hline SF & $1022(350)$ & $283.7(1.4)^{\mathrm{a}}$ & $28.7(1.2)^{\mathrm{a}}$ & $7.9(0.4)^{\mathrm{a}}$ \\
\hline FAS & $1022(350)$ & $71.2(3.5)^{\mathrm{b}}$ & $6.25(0.2)^{\mathrm{b}}$ & $3.1(0.9)^{\mathrm{b}}$ \\
\hline
\end{tabular}

The results reported are means of triplicate samples and SD in brackets. Different superscript letters, in the same column, indicate significantly different $(p<0.05)$ samples. SF spontaneous fermentation, FAS: fermentation with the addition of mixed-starter. 
Table 2. Pasting properties of cassava flours at 24 hours of fermentation.

\begin{tabular}{cccccccc}
\hline \multirow{2}{*}{ Treatments } & \multicolumn{7}{c}{ Pasting properties } \\
\cline { 2 - 8 } & $\operatorname{Pt~}\left({ }^{\circ} \mathrm{C}\right)$ & $\mathrm{PV}(\mathrm{cP})$ & $\mathrm{BV}(\mathrm{cP})$ & FV $(\mathrm{cP})$ & SV $(\mathrm{cP})$ & Set & Sta \\
\hline UCF $^{*}$ & $71.7(2.1)^{\mathrm{a}}$ & $5205(156)^{\mathrm{a}}$ & $2627(79)^{\mathrm{a}}$ & $3580(107)^{\mathrm{a}}$ & $1002(30)^{\mathrm{a}}$ & $1.4(0.0)^{\mathrm{b}}$ & $0.5(0.0)^{\mathrm{a}}$ \\
$\mathrm{SF}$ & $72.7(1.4)^{\mathrm{a}}$ & $5214(12)^{\mathrm{a}}$ & $2667(57)^{\mathrm{ab}}$ & $3602(32)^{\mathrm{a}}$ & $979(32)^{\mathrm{a}}$ & $1.4(0.1)^{\mathrm{b}}$ & $0.5(0.0)^{\mathrm{a}}$ \\
FAS & $70.5(0.5)^{\mathrm{a}}$ & $5271(13)^{\mathrm{a}}$ & $2752(12)^{\mathrm{b}}$ & $3510(39)^{\mathrm{a}}$ & $992(14)^{\mathrm{a}}$ & $1.3(0.1)^{\mathrm{a}}$ & $0.5(0.0)^{\mathrm{a}}$ \\
\hline
\end{tabular}

The results reported are means of triplicate samples and SD in brackets. Different superscript letters, in the same column, indicate significantly different $(p<0.05)$ samples. UCF: unfermented cassava flour, SF spontaneous fermentation, FAS: fermentation with the addition of mixed-starter, Pt: pasting time; PV: peak viscosity; BV: breakdown viscosity, FV: final viscosity, SV: setback viscosity, Set: setback ratio, Sta: stability ratio.

Table 3. Pasting properties of cassava flours at 48 hours of fermentation.

\begin{tabular}{cccccccc}
\hline \multirow{2}{*}{ Treatments } & \multicolumn{7}{c}{ Pasting properties } \\
\cline { 2 - 8 } & $\mathrm{Pt}\left({ }^{\circ} \mathrm{C}\right)$ & $\mathrm{PV}(\mathrm{cP})$ & $\mathrm{BV}(\mathrm{cP})$ & $\mathrm{FV}(\mathrm{cP})$ & $\mathrm{SV}(\mathrm{cP})$ & Set & Sta \\
\hline $\mathrm{UCF}^{*}$ & $71.7(2.1)^{\mathrm{a}}$ & $5205(156)^{\mathrm{a}}$ & $2627(79)^{\mathrm{a}}$ & $3580(107)^{\mathrm{b}}$ & $1002(30)^{\mathrm{a}}$ & $1.4(0.0)^{\mathrm{a}}$ & $0.5(0.0)^{\mathrm{a}}$ \\
$\mathrm{SF}$ & $72.2(1.3)^{\mathrm{a}}$ & $6420(35)^{\mathrm{b}}$ & $3605(91)^{\mathrm{c}}$ & $3086(70)^{\mathrm{a}}$ & $1081(11)^{\mathrm{b}}$ & $0.9(0.0)^{\mathrm{c}}$ & $0.6(0.0)^{\mathrm{b}}$ \\
FAS & $70.4(1.2)^{\mathrm{a}}$ & $5749(20)^{\mathrm{c}}$ & $3160(34)^{\mathrm{b}}$ & $3813(69)^{\mathrm{c}}$ & $1224(15)^{\mathrm{c}}$ & $1.2(0.2)^{\mathrm{b}}$ & $0.5(0.0)^{\mathrm{a}}$ \\
\hline
\end{tabular}

The results reported are means of triplicate samples and SD in brackets. Different superscript letters, in the same column, indicate significantly different $(p<0.05)$ samples. UCF: unfermented cassava flour, SF spontaneous fermentation, FAS: fermentation with the addition of mixed-starter, Pt: pasting time; PV: peak viscosity; BV: breakdown viscosity, FV: final viscosity, SV: setback viscosity, Set: setback ratio, Sta: stability ratio.

Table 4. Pasting properties of cassava flours at 72 hours of fermentation.

\begin{tabular}{cccccccc}
\hline \multirow{2}{*}{ Treatments } & \multicolumn{7}{c}{ Pasting properties } \\
\cline { 2 - 8 } & $\mathrm{Pt}\left({ }^{\circ} \mathrm{C}\right)$ & $\mathrm{PV}(\mathrm{cP})$ & $\mathrm{BV}(\mathrm{cP})$ & $\mathrm{FV}(\mathrm{cP})$ & $\mathrm{SV}(\mathrm{cP})$ & Set & Sta \\
\hline $\mathrm{UCF}^{*}$ & $71.7(2.1)^{\mathrm{c}}$ & $5205(156)^{\mathrm{a}}$ & $2627(79)^{\mathrm{a}}$ & $3580(107)^{\mathrm{a}}$ & $1002(30)^{\mathrm{a}}$ & $1.4(0.0)^{\mathrm{c}}$ & $0.5(0.0)^{\mathrm{a}}$ \\
$\mathrm{SF}$ & $71.5(1.5)^{\mathrm{b}}$ & $6615(14)^{\mathrm{c}}$ & $4186(8)^{\mathrm{c}}$ & $3501(3)^{\mathrm{a}}$ & $1068(2)^{\mathrm{b}}$ & $0.8(0.0)^{\mathrm{a}}$ & $0.6(0.0)^{\mathrm{b}}$ \\
$\mathrm{FAS}$ & $70.3(0.1)^{\mathrm{a}}$ & $5986(32)^{\mathrm{b}}$ & $3596(66)^{\mathrm{b}}$ & $3425(92)^{\mathrm{a}}$ & $1034(17)^{\mathrm{ab}}$ & $0.9(1.2)^{\mathrm{b}}$ & $0.6(0.0)^{\mathrm{b}}$ \\
\hline
\end{tabular}

The results reported are means of triplicate samples and SD in brackets. Different superscript letters, in the same column, indicate significantly different $(p<0.05)$ samples. UCF: unfermented cassava flour, SF spontaneous fermentation, FAS: fermentation with the addition of mixed-starter, Pt: pasting time; PV: peak viscosity; BV: breakdown viscosity, FV: final viscosity, SV: setback viscosity, Set: setback ratio, Sta: stability ratio.

The pasting parameters (Table 2) of cassava flours made from cassava roots after $24 \mathrm{~h}$ of fermentation were evaluated. The pasting temperature of SF and FAS cassava flour was $72.7^{\circ} \mathrm{C}$ and $70.5^{\circ} \mathrm{C}$, respectively. The pasting temperatures of the fermented flours were not significantly different from the unfermented flour $\left(71.7^{\circ} \mathrm{C}\right)$. These results indicate a weak granular structure of cassava compare to cocoyam $\left(78^{\circ} \mathrm{C}\right.$ pasting temperature) [2] (Oke and Bolanriwa, 2012). The peak viscosity (PV), Breakdown viscosity (BV), Final viscosity (FV) and Setback viscosity (SV) of the SF and FAS cassava flours were not significantly different from the unfermented flour, and indicates that no major modifications occurs in starch granules of cassava root after $24 \mathrm{~h}$ of the fermentation. However a significant difference was observed between setback ratio of FAS flour (1.3) and un- 
fermented flour (1.4). This result shows that FAS flour is less consistence than UCF and SF.

The pasting parameters (Table 3) of cassava flours made from cassava roots after $48 \mathrm{~h}$ of fermentation were evaluated. Unfermented cassava flour has peak viscosity of $5205 \mathrm{cP}$, while peak viscosity of SF and FAS flours was $6420 \mathrm{cP}$ and $5749 \mathrm{cP}$ respectively. Increase of $\mathrm{PV}$ is associated with enzymatic activity during fermentation process [12] (Farasara et al., 2014). Amylase hydrolyzes $\alpha$-1, 4-Dglycosidic bond of starch thus the structure of starch granule becomes more porous facilitating water absorption to granules. This will increase PV [13] (Claver et al., 2012). Flour with a lower peak viscosity has a lower thickening power than flour with higher peak viscosity; therefore FAS flour has a lower thickening power than SF flour and $24 \mathrm{~h}$ fermented cassava flour has a lower thickening power than $48 \mathrm{~h}$ fermented flour. The final viscosity of SF flour and FAS flour after $48 \mathrm{~h}$ of fermentation $(3086 \mathrm{cP}$ and $3813 \mathrm{cP}$ ) was significantly different from the unfermented cassava flour $(3580 \mathrm{cP})$. This result shows that, amylose content is higher in FAS flour followed by unfermented flour than in SF flour. Increase of FV can be associated with marked activity of amylases that hydrolyses amylopectin and thus releases polymeric chains of 15 monomer units which physicochemical properties are similar to those of amylose [14].

Breakdown viscosity (BV) is the degree of viscosity reduction during heating process. It can be used as an indicator for pasting stability during the heating and stirring 2 . The SF flour had the highest breakdown viscosity $(3160 \mathrm{cP})$, while the UCF flour had the lowest one $(2627 \mathrm{cP})$. SF flour paste (stability ratio $=0.6$ ) was also more resistant to shear thinning than FAS and UCF (stability ratio = 0.5) (Table 3). This finding indicates that, SF flour has the ability to withstand severe processing conditions better than FAS and UCF pastes [15]. Breakdown viscosity values were also highest in the $48 \mathrm{~h}$ fermented flours than the $24 \mathrm{~h}$ fermented flours (Table 2). Breakdown increased with the increase in the fermentation period of the flour samples. This suggest that, the swollen starch granules of fermented flours can be easily been disintegrated than those of Unfermented starch granules. Thus, unfermented starch granules are more stable during heating process than fermented starch granules [16].

The setback viscosity (SV) (Table 3) of fermented flours SF and FAS were $1081 \mathrm{cP}$ and $1224 \mathrm{cP}$, respectively. Those values were highest than the SV of UCF $(1002 \mathrm{cP})$. The setback obtain in this study indicates a higher retrogradation tendency of fermented cassava flour, particularly FAS flour. This property of FAS flour makes it suitable for use in jelly foods [2].

Continued fermentation process of cassava roots up to 48 hours of fermentation, result in cassava flour with their respective pasting parameters presented in Table 4. As we can see in this table, final viscosity and setback viscosity of fermented flours were not significantly different from those of unfermented cassava flour. However, the pasting temperature of SF flour $\left(71.5^{\circ} \mathrm{C}\right)$ was higher than the pasting temperature of $\mathrm{UCF}\left(71.7^{\circ} \mathrm{C}\right)$; while the pasting temperature of FAS flour $\left(70.3^{\circ} \mathrm{C}\right)$ was lower than the one of UFC. The peak viscosity of FAS flour 
was higher than the peak viscosity of UCF. Lower pasting temperature and rapid rise in peak viscosity indicate a weak granular structure of FAS flour at $72 \mathrm{~h}$ of fermentation. In general, the PV value of fermented cassava flours continued to increase to $6615 \mathrm{cP}(\mathrm{SF})$ and $5986 \mathrm{cP}$ (for FAS) with the period of the fermentation. This was also observed with the BV value of those flours. This is an indication of the weak elasticity and weak consistence of fermented flours comparing with unfermented cassava flour. The setback ratio of UCF (1.4) flour paste was higher than the one of fermented cassava flour pastes SF (0.8) and FAS (0.9), indicating that dispersed UCF flour has a higher rate of retrogradation due to the association of the leached amylose molecules.

\section{Conclusion and Recommendation}

Fermentation affected the total cyanides content and pasting properties of cassava flour. Cyanides content was reduced significantly. The greatest reduction was observed in the FAS cassava flour, with the cyanides reductions level of $98 \%$ and $99 \%$ respectively, at $48 \mathrm{~h}$ and $72 \mathrm{~h}$ of fermentation. This reduction was faster with the addition of starter compared to spontaneous fermentation. Pasting parameters increased markedly after $24 \mathrm{~h}$ of fermentation. Then, at $46 \mathrm{~h}$ of fermentation, SF flour paste was more resistant to shear thinning than FAS and UCF, indicating that, SF flour has the ability to withstand severe processing conditions better than FAS and UCF pastes. The use of mixed-starter culture resulted in cassava flour with higher value of PV, SV and FV after $48 \mathrm{~h}$ of fermentation, which decreased when fermentation was prolonged at $72 \mathrm{~h}$. Further study need to be carried out on chemical composition as well as functional properties of fermented cassava flour and if possible, to characterize the microorganisms in 96 hours of fermented flour used as starter in this work.

\section{Acknowledgements}

This publication is an output of a project funded by European Union (contrat de subvention $n^{\circ}$ dci-food/2010/252-886), with the support of AIRD (Agence Inter-Etablissements de Recherche pour le Développement).

\section{References}

[1] FAO. http://www.fao.org

[2] Oke, M.O. and Bolanriwa, I.F. (2012) Effect of Fermentation on Physicochemical Properties and Oxalate Content of Cocoyam (Colocasia esculenta) Flour. International Scholarly Research Network (ISRN) Agronomy, 2012, Article ID: 978709. https://doi.org/10.5402/2012/978709

[3] Nassar, N.M.A. and Marques, A.O. (2006) Cassava Leaves as a Source of Protein. Journal of Food, Agriculture and Environment, 4, 187-188.

[4] Teles, F.F.F. (2002) Chronic Poisoning by Hydrogen Cyanide in Cassava and Its Prevention in Africa and Latin America. Food Nutrition Bulletin, 23, 407-412. https://doi.org/10.1177/156482650202300416

[5] Cardoso, A.P., Mirione, E., Ernesto, M., Massaza, F., Cliff, J., Haque, M.R. and 
Bradbury, J.H. (2005) Processing of Cassava Roots to Remove Cyanogens. Journal of Food Composition and Analysis, 18, 451-460.

[6] Younoussa, D., Momar, T., Gueye, M.S., Praxède, G.D., Amadou, K.J.P. and Lognay, B.G. (2013) Importance nutritionnelle du manioc et perspectives pour l'alimentation de base au Sénégal (synthèse bibliographique). Biotechnologie Agronomie Sociologie et Environnement, 17, 634-643.

[7] Numfor, F.A. (1999) Physicochemical Changes in Cassava Starch and Flour Associated with Fermentation, Effect on Textural Properties. Journal of Food Technology in Africa, 4, 31-35.

[8] Bradbury, G.M., Egan, S.V. and Bradbury, J.H. (1999) Picrate Paper Kits for Determination of Total Cyanogens in Cassava Roots and All Forms of Cyanogens in Cassava Products. Journal of the Science of Food and Agriculture, 79, 593-601. https://doi.org/10.1002/(SICI)1097-0010(19990315)79:4<593::AID-JSFA222>3.0.CO $\underline{; 2-2}$

[9] Westby, A. and Choo, B.K. (1994) Cyanogens Reduction during the Lactic Fermentation of Cassava. Acta Horticulture, 375, 209-215. https://doi.org/10.17660/ActaHortic.1994.375.19

[10] Ampe, F., Brauman, A., Trèche, S. and Agossou, A. (1994) The Fermentation of Cassava: Optimization by the Experimental Research Methodology. Journal of Sciences Food and Agriculture, 65, 355-361. https://doi.org/10.1002/jsfa.2740650314

[11] Kobawila, S.C., Louembe, D., Keleke, S., Hounhouigan, J. and Gamba, C. (2005) Reduction of the Cyanide Content during Fermentation of Cassava Roots and Leaves to Produce Bikedi and Ntoba Mbodi, Two Food Products from Congo. African Journal of Biotechnology, 4, 689-696. https://doi.org/10.5897/AJB2005.000-3128

[12] Farasara, R., Hariyadi, P., Fardiaz, D. and Dewanti-Hariyadi, R. (2014) Pasting Properties of White Corn Flours of Anoman 1 and Pulut Harapan Varieties as Affected by Fermentation Process. Food and Nutrition Sciences, 5, 2038-2047. https://doi.org/10.4236/fns.2014.521215

[13] Claver, I.P., Li, Q., Zhu, K. and Zhou, H. (2010) Impact of the Soak and the Malt on Physicochemical Properties of the Sorghum Starches. International Journal of Molecular Sciences, 11, 3002-3015. https://doi.org/10.3390/ijms11083002

[14] Lu, T.J., Chen, J.C., Lin, C.L. and Chang, Y.H. (2005) Properties of Starches from Cocoyam (Xanthosoma sagittifolium) Tubers Planted in Different Seasons. Food Chemistry, 91, 69-77.

[15] Zeng, F., Hong, L. and Gang, L. (2014) Physicochemical Properties of Starch Extracted from Colocasia esculenta (L.) Schott (Bun-Long Taro) Grown in Hunan, China. Starch/Stärke, 66, 142-148. https://doi.org/10.1002/star.201300039

[16] Singh, N., Singh, J., Kaur, L., Sodhi, N.S. and Gill, B.S. (2003) Morphological, Thermal and Rheological Properties of Starches from Different Botanical Sources. Food Chemistry, 81, 219-231. 
Submit or recommend next manuscript to SCIRP and we will provide best service for you:

Accepting pre-submission inquiries through Email, Facebook, LinkedIn, Twitter, etc. A wide selection of journals (inclusive of 9 subjects, more than 200 journals)

Providing 24-hour high-quality service

User-friendly online submission system

Fair and swift peer-review system

Efficient typesetting and proofreading procedure

Display of the result of downloads and visits, as well as the number of cited articles Maximum dissemination of your research work

Submit your manuscript at: http://papersubmission.scirp.org/

Or contact fns@scirp.org 